\title{
The effect of biologization of growing wine grapes on the microbocenosis of a vineyard
}

\author{
$N$ Klimenko, ${ }^{1, *}$ \\ ${ }^{1}$ Research Institute of Agriculture of Crimea, 150, Kievskaya Street, 295493, Simferopol, Russian \\ Federation
}

\begin{abstract}
This article presents the results of a microbiological study of soil samples selected in the vineyard in the berry growth stage in 20162017, aimed at studying the number of bacteria of the main ecological and trophic groups involved in the transformation of soil organic matter. It is shown that the combined use of microbial preparations and grassing contributed to an increase in the number of bacteria in the rhizosphere of the grape. Thus, the greatest number of ammonifying, amylolytic and oligonitrophilic bacteria were observed against the background of bluegrass grassing: the excess of control was 2.9, 1.3 and 1.2 times, respectively. At the same time, it was revealed that in comparison with the control, the number of phosphate-mobilizing and oligotrophic bacteria was greatest in natural grassing.
\end{abstract}

\section{Introduction}

Viticulture is a highly profitable branch of agricultural production of the Russian Federation, which occupies one of the main sources of income in its southern regions. However, the cultivation of grapes is often associated with a negative anthropogenic impact on all components of ampelocenosis: plants, soil (treatment by the type of black fallow), microorganisms, etc. [1]. This is due to repeated tillage, the fight against diseases and pests, the introduction of large doses of organic and mineral fertilizers, which are known to be only partially absorbed by plants, which eventually leads to environmental pollution. Therefore, it is necessary to find new, environmentally friendly ways to increase plant productivity and improve the quality of yield. In this regard, methods of biologization are used in viticulture. These include soil grassing, as well as the use of MP as a biofertilizer [2-4].

The grassing of the soil between the rows with perennial grasses promotes the inflow of fresh organic matter into the soil with the plant fall of grasses, which serves as an additional source of nutrition for soil microorganisms, and this in turn leads to an increase in the content of mobile nutrients to improve the growth and productivity of plants. Grasses also contribute to the improvement of soil structure and its water-physical properties due to the branched root system [5-6]. It is known that the use of MP based on effective strains of

\footnotetext{
* Corresponding author: ninaklymenko@yandex.ru
} 
microorganisms has a positive effect on the growth and development of agricultural plants, increasing yields and product quality, in particular, grapes [7-12].

\section{Materials and methods}

The research was carried out in the vineyard of L.L.C. "Vinograd plus" (Khmelnitsky village, Balaklava district, Sevastopol, Russian Federation) in 2016-2017. The soil of the area is the meadow-alluvial carbonate, slightly humus, heavy loamy and has following main characteristics: humus content - 1.5-2.2\%; mobile forms of nitrogen, phosphorus and potassium - 11-18, 32-28 and $260-430 \mathrm{mg} / \mathrm{kg}$ of soil, respectively; $\mathrm{pH}$ of soil solution 8.2-8.5; content of carbonates and active lime $-15-37$ and 10-15\% respectively. Grape variety is Chardonnay on the rootstock Berlandieri x Riparia Cober 5 BB. Grape training is Guyot. Planting scheme was $2.5 \times 0.9 \mathrm{~m}$. Plot area was $45 \mathrm{~m}^{2}$. The number of plants on the registration plot was 20 bushes. Placement of accounting plots - randomized. The soil between the rows was under grassing: natural ( $\mathrm{NG}$ - plants typical for this soil-climatic zone), perennial ryegrass (Lolium perenne L.) and bluegrass (Poa pratensis L.). As a biofertilizer, a complex of microbial preparations (CMP) was used, consisting of bioagents of microbial preparations Diazophyt (Agrobacterium radiobacter 204 - diazotroph, improves nitrogen nutrition of plants, enhances their growth), Phosphoenterin (Enterobacter nimipressuralis 32-3 - improves phosphorus nutrition of plants, improves their growth and product quality, produces phytohormones) and Biopolytsid (Paenibacillus polymyxa $\mathrm{P}$ - has nitrogen-fixing and bioprotective properties). Scheme of field experiment: 1. Control (NG); 2. CMP (NG); 3. Control (ryegrass); 4. CMP (ryegrass); 5. Control (bluegrass); 6. CMP (bluegrass). Soil samples for microbiological analysis were taken from a depth of 0-30 and 30-60 cm, respectively, in the berry growth phase. The number of bacteria of the main ecological-trophic groups was estimated by direct inoculation of soil suspension on the appropriate culture medium [13]. Statistical processing of the results was carried out using Microsoft Excel.

\section{Results and discussion}

Our studies showed that the number of bacteria of ecological-trophic groups in the rhizosphere of grapes, studied by us, in the soil layer $0-30 \mathrm{~cm}$ was higher than in the layer of 30-60 cm: an average of $59 \%$ in the control and $48 \%-$ when using the CMP. This is explained by the fact that with a decrease in the depth of the soil profile, the supply of nutrients and the content of fresh organic matter decreases [14].

It is known that the decomposition of organic compounds of nitrogen, entering in large quantities into the soil of the vineyard with the plant litter, is performed mainly by ammonifying bacteria. This leads to the replenishment of the soil with nutrients available for plants [11]. Our studies have shown that on the background of natural grassing in the control the number of bacteria of this group of microorganisms was 80.7 million colony forming units per gram of absolutely dry soil (CFU/g a.d.s.) in the soil layer $0-30 \mathrm{~cm}$ and 50.4 million - in the soil layer $30-60 \mathrm{~cm}$ (fig. 1). 


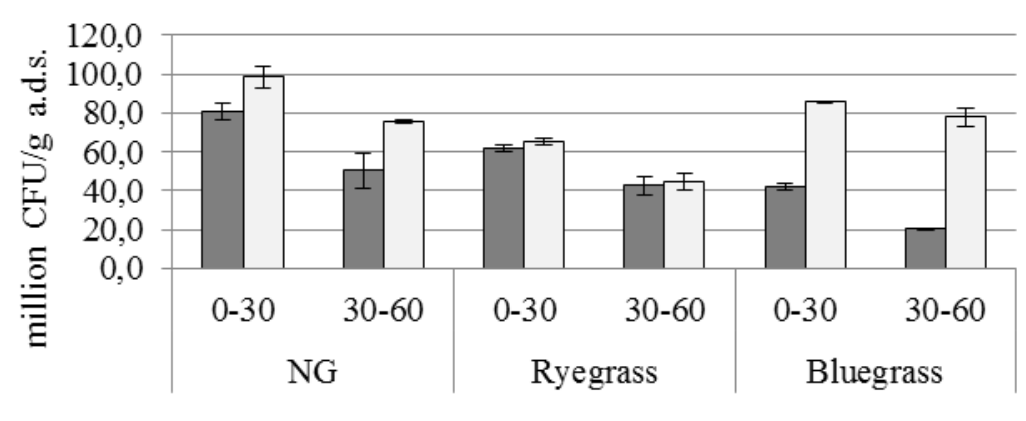

$\square$ Control $\square \mathrm{CMP}$

Fig. 1. Number of ammonifying bacteria in the rhizosphere of Chardonnay grapes.

During the bacterization of the rhizosphere of grapes with the CMP, an increase in the number of ammonifying bacteria was observed by $22 \%$ and $50 \%$ in the soil layer $0-30$ and $30-60 \mathrm{~cm}$, respectively. It is shown that the number of ammonifying bacteria decreased when the soil between rows was grassed with ryegrass compared to NG: in the control it was 62.0 and 42.9 million, and when using CMP - 65.3 and 44.7 million CFU/g a.d.s. in the soil layer 0-30 and 30-60 cm, respectively. A similar tendency was observed when the soil was grassed with bluegrass. In the control, the number of bacteria of this ecologicaltrophic group was 41.9 million CFU in the soil layer $0-30 \mathrm{~cm}$ and 20.3 million CFU/g a.d.s. - in the soil layer 30-60 cm. However, when applying CMP, their number increased by 2.0 3.8 times compared to the control. In our opinion, the smaller number of bacteria when grassed with ryegrass and bluegrass compared to NG due to their component composition, providing an advantage over mono grassing.

Amylolytic bacteria participate in the process of microbiological binding of mineral nitrogen formed as a result of ammonification of protein substances of plant residues and organic fertilizers, thereby improving the nitrogen nutrition of plants [15]. It is shown that against the background of NG in the control the number of bacteria of this ecologicaltrophic group was in the soil layer $0-30$ and $30-60 \mathrm{~cm} 54.1$ and $38.2 \mathrm{million} \mathrm{CFU} / \mathrm{g}$ a.d.s., respectively (fig. 2).

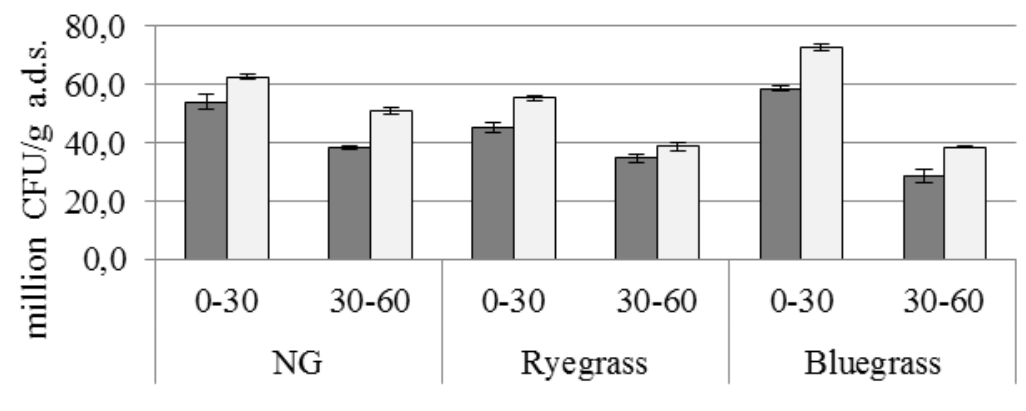

$\square$ Control $\square \mathrm{CMP}$

Fig. 2. Number of amylolytic bacteria in the rhizosphere of Chardonnay grapes.

The use of CMP contributed to an increase in their number by 16 and $34 \%$ in the layer 0-30 and 30-60 $\mathrm{cm}$ against the control, respectively.

When the soil between the rows was grassed, the number of these bacteria in comparison with NG slightly decreased, but the provision of soil remained at a high level: 
45.3 and 34.7 million CFU/g a.d.s. in the control and 55.5 and 38.8 million CFU with applying of CMP in the layer 0-30 and 30-60 cm, respectively. Against the background of grassing the soil between the rows with bluegrass, the number of amylolytic bacteria was the largest in comparison with other types of grassing studied by us. It was 58.6 and 28.6 million CFU/g a.d.s. in the control and 72.6 and 38.6 million CFU when bacterization of CMP in the soil layer 0-30 and 30-60 cm, respectively.

We also studied the number of phosphate-mobilizing bacteria. Microorganisms of this group in the soil play an important role in providing plants with easily digestible phosphorus compounds. Thus, studies have shown that the greatest number of bacteria of this group is noted on the background of $\mathrm{NG}$ of the soil between the rows of the vineyard. In the control it was 45.4 and 32.7 million CFU/g a.d.s in the layer of $0-30$ and $30-60 \mathrm{~cm}$, respectively, and when the bacterization of the rhizosphere with CMP -60.3 and 38.5 million (fig. 3).

There was a decrease in the number of phosphate-mobilizing bacteria on the background of grassing the soil between the rows with ryegrass, which may be due to a smaller input of fresh organic matter into the soil. It amounted to 28.4 and 19.7 million CFU/g a.d.s. in a layer $0-30$ and $30-60 \mathrm{~cm}$ in the control and 31.0 and 20.9 million CFU when using CMP, respectively. When the soil between rows of the vineyard was grassed with bluegrass, a slightly higher number of bacteria was noted, compared with ryegrass: in the control it was 36.0 and 26.2 million CFU/g a.d.s. in the soil layer 0-30 and 30-60 cm, respectively. When introduced into the rhizosphere, the number of bacteria increased slightly compared to the control by 2-31\% compared to the control in the soil layer of $0-30$ and $30-60 \mathrm{~cm}$, respectively.

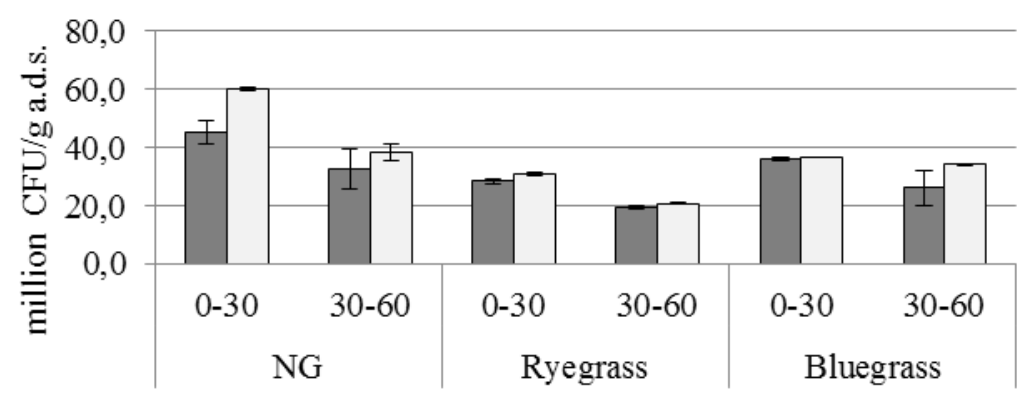

$\square$ Control $\square \mathrm{CMP}$

Fig. 3. Number of phosphate-mobilizing bacteria in the rhizosphere of Chardonnay grapes.

Oligonitrophilic bacteria can grow in a small amount of available nitrogen in the soil solution, they also have the ability to non-symbiotic nitrogen fixation, enriching the rhizosphere of grapes with mineral nitrogen compounds [15]. Our studies have shown that the number of bacteria of this ecological-trophic group in the control against the background of NG was in the layer $0-30$ and $30-60 \mathrm{~cm} 42.0$ and 30.0 million CFU/g a.d.s., respectively (fig. 4). 


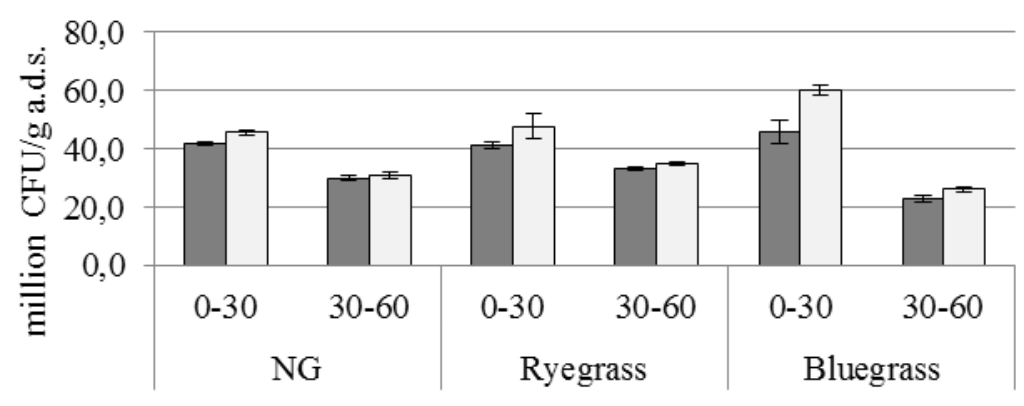

$\square$ Control $\square \mathrm{CMP}$

Fig. 4. Number of oligonitrophilic bacteria in the rhizosphere of Chardonnay grapes.

The use of CMP contributed to an increase in the number of oligonitrophilic bacteria in the rhizosphere of Chardonnay grapes: by 3-9 \% against control. Against the background of grassing the soil between the rows by ryegrass, the number of bacteria in the rhizosphere increased compared to the previous background of grassing. Thus, in the control it was 41.1 and 33.3 million CFU, and in the version using the CMP - 47.8 and 34.9 million CFU/g a.d.s. in a layer $0-30$ and $30-60 \mathrm{~cm}$, respectively. Against the background of grassing the soil between the rows with bluegrass in the control the number of bacteria in the rhizosphere of Chardonnay grapes in a layer $0-30 \mathrm{~cm}$ was 46.1 million CFU, and when bacterization with CMP -60.4 million CFU/g a.d.s. In the control in the layer $30-60 \mathrm{~cm}$ number of bacteria was at the level of 22.8 and 26.2 million - with the bacterization with CMP.

As the concentration of simple sugars, proteins and low-molecular-weight fatty acids in the soil decreases, the primary hydrolytics are replaced by microflora of oligotrophic group, which utilizes organic matter at the final stage of its transformation. The reason for this is the ability of oligotrophic bacteria to exist in conditions with a low concentration of available food components. Our studies have shown that the greatest number of bacteria in this group was observed when the soil was grassed with bluegrass (fig. 5).

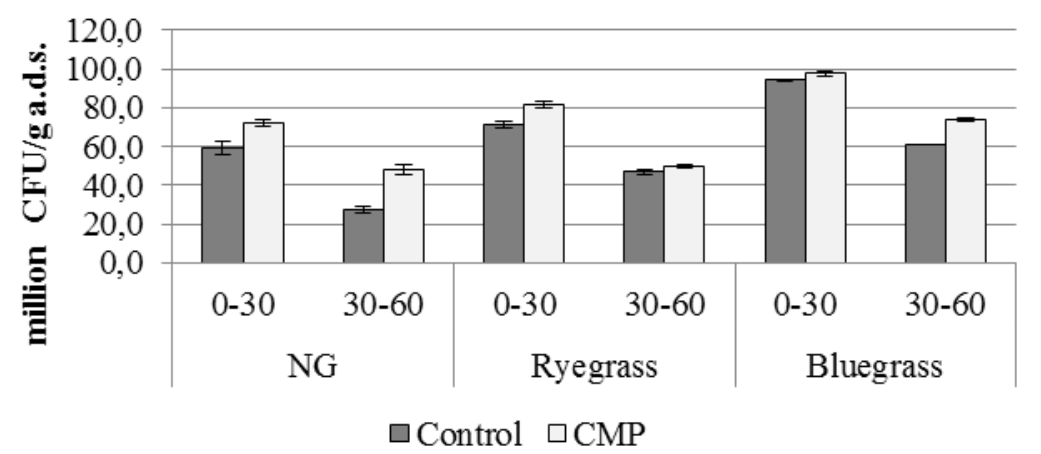

Fig. 5. Number of oligotrophic bacteria in the rhizosphere of Chardonnay grapes.

Thus, on this background, the number of oligotrophic bacteria in the control was 94.4 and 61.1 million CFU/g a.d.s. When applying CMP, their number increased by $4-20 \%$ compared to the control in soil layers 0-30 and 30-60 cm, respectively.

Against the background of grassing with ryegrass, the number of oligotrophic bacteria in the rhizosphere of the grape plant slightly decreased compared to grassing with 
bluegrass, but was higher than on NG. In the control it was at the level of 71.1 and 47.1 million CFU/g a.d.s., and with bacterization - 81.7 and 49.9 million CFU/g a.d.s. in the soil layer $0-30$ and $30-60 \mathrm{~cm}$, respectively. Against the background of natural grassing, the number of oligotrophic bacteria was the smallest, but the introduction of CMP into the rhizosphere contributed to its increase in comparison with the control by $22-73 \%$ in the soil layer 0-30 and 30-60 cm, respectively.

\section{Conclusions}

Thus, in conclusion, it should be noted that the use of microbial preparation CMP on different types of grassing had a positive impact on the number of bacteria of the main ecological and trophic groups in the rhizosphere of Chardonnay grapes. Thus, with bacterization, depending on the background of grassing, the number of ammonifying bacteria increased compared to the control by 5-194\%, amylolytic - by 17-29\%, phosphate-mobilizing - by $8-25 \%$, oligonitrophilic - by $6-23 \%$ and oligotrophic - by $10-$ $47 \%$.

\section{References}

1. Lukyanov A A, Kuznetsov G Ya 2013 Ways to reduce soil degradation of vineyards Proceedings of the Symposium "Development of fundamental research on the problems of agrogenic transformation of soils in monoculture" (Krasnodar) 74-78

2. Klimenko N N 2016 Microbial preparations as a factor of growing productivity and product quality of Muscat white grapes Taurida Herald of the Agrarian Sciences 4(8) $22-30$

3. Belkov A S 2019 The agrotechnological methods of maintaining the soil of the vineyards to obtain high-quality wine products Scientific works of the North Caucasus Federal scientific center of horticulture, viticulture, and winemaking 26 205-209

4. Vorobeva T N, Volkova A A, Veter Yu A 2013 The experience of practical application of the principles of biological farming at the Taman vineyard Scientific works of State Scientific Institution North-Caucasus Zonal Research Institute of Horticulture and Viticulture of the Russian Academy of Agricultural Sciences 3 112-115

5. Petrov V S 2018 Methodology of control of ampelocenoses stability and productivity and quality of production under the conditions of anthropogenic intensification of production, global and local climate change Scientific works of the North Caucasus federal scientific center of horticulture, viticulture, winemaking 15 7-15

6. Mikheev E M, Petrov V S 2018 Effect of the sowing between soil rows on productivity and qualitative indicators of grapes and wine Fruit growing and viticulture of South Russia 52(4) 147-155

7. El-Boray M S, Mostafa M F, Shaltout A D, Hassan K H 2015 Influence of fulvic acid plus some microelements and microorganisms on yield and quality characteristics of superior seedless grapevines Journal of Plant Production 6(3) 287-305

8. Liu M, Liu X, Cheng B-S et al 2016 Selection and evaluation of phosphate-solubilizing bacteria from grapevine rhizospheres for use as biofertilizers Spanish journal of agricultural research 14(4) 26-35

9. Konovalov S N, Petrova V I 2013 Efficiency of biofertilizers in biologized precision technologies of cultivation of garden crops Proceedings of the Symposium "Development of fundamental research on the problems of agrogenic transformation 
of soils in monoculture" 63-71

10. Raicevic V, Sivcev B, Jakovljevic M, Antic S, Lalevic B 2003 The Environmental Impact of Viticulture: "The Influence Of Biofertilizer Type On Wine Quality And Soil Microbiological Activity" Proceedings of Ist International Symposium on Grapevine Growing, Commerce and Research vol 652 (Acta Hort.) 309-313

11. Sivčev B, Jović S, Raičević V, Petrović A, Lalević B 2005 Application of microbiological fertilizers in viticulture: grape yield and quality of wine cv. Riesling Journal of Agricultural Sciences 50(1) 19-26

12. Tikhonovich I A, Zavalin A A 2016 Application potential of nitrogen-fixing and phytostimulating microorganisms for increasing the efficiency of the agroindustrial complex and improving the agroecological situation in Russian Federation Plodorodie 5(92) 28-32

13. Tepper E Z, Shilnikova V K, Pereverzeva G I 2004 Practicum on Microbiology: a textbook for universities (Moscow: Drofa) 256

14. Netrusov A I, Bonch-Osmolovskaya E A, Gorlenko V M et al Ecology of microorganisms: studies. for students. universities ed A I Netrusov (Moscow: Academy) 272

15. Titova V I, Kozlov A V 2012 Methods for assessing the functioning of soil microbiocenosis involved in the transformation of organic matter: Scientific and methodological guide (Nizhny Novgorod: agricultural Academy) 64 